\title{
A Screening Method for Test Substances on Attachment Using Larval Barnacle, Balanus amphitrite, in the Laboratory.*
}

\author{
Ichiro KATSUYAMA \\ Japan NUS Co., LTD. Shin-ykohama, Kohoku, Yokohama 222 \\ Ryusuke KaDo \\ School of Fisheries Sciencies, Kitasato University, Sanriku, Iwate 022-01 \\ Hirohiko Kominami \\ Technical Research Center, Kansai Electric Power Co. Wakoji, Amagasaki 661 \\ and \\ Hitoshi KitAmura \\ Faculty of Fisheries, Nagasaki University, Bunkyoucho, Nagasaki 852
}

(Received April 8, 1992)

Methods for the screening of substances that induce or inhibit the attachment of barnacle cyprids have been reported by RITTSCHOF et al. (1984) and MAKI et al. (1988). However, these methods were not suitable for the evaluation of selectivity for substrata by the larvae simultaneously. In their methods, cyprids were placed into polystyrene petri dishes coated with or without test materials or microorganisms, so that the cyprids in the a dish could have no chance to select substrata. Therefore, another methods is required to compare the effect for attachment in the same experimental vessel.

We developed a screening method that takes advantage of the selectivity for substrata by cyprids at the same time, and examined its practicality. Balanus amphitrite DARwIN was used as test orgamism. Nauplii of this species were reared until stage VI to cyprid at $24^{\circ} \mathrm{C}$ with diatom Chaetoceros calcitrans as food (KADO, 1991). The experimental equipment consists of a plastic water tank, a cage and a water pump (Fig. 1). The cage, made by converting a plankton net of $96 \mu \mathrm{m}$ meshes into a bag form $(20 \times 15 \times 10$ $\mathrm{cm}$ ), was used to prevent cyprids from settling on the wall of tank, and suspended into the tank containing 8 liter of seawater. The sea-

* This study was presented at the annual meeting of the Japanese Society of Scientific Fisheries, Tokyo, April, 1990.

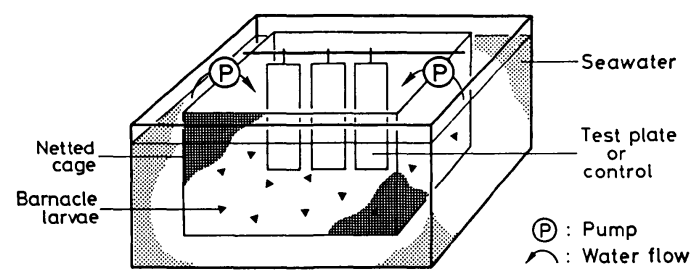

Fig. 1. Screening equipment using larval barnacle.

water was continuously circulated and poured from the tank into cage by the water pump, creating a water current. Fifteen each of glass plates $(25 \times 75 \times 2 \mathrm{~mm}$, as control $)$ and the same size test plates were fixed onto stainless steel wires and hung down into the cage at random. When about one-third of the reared nauplii metamorphosed into cyprid (about six days after hatching), approximately 1000 of naupliiand cyprid were placed into the cage. The larvae were kept at $24^{\circ} \mathrm{C}$ for $72 \mathrm{hrs}$ under a dark condition and then the number of those underwent metamorphosis after attachment to the test plates and control plates were counted.

Using this methods, we performed two experiments on the reaction of barnacle larvae; 1) to a slime and 2) to an antifouling paint. The slime was developed on glass plates immersed for one week into the sea $(1 \mathrm{~m}$ in depth) in Aburatsubo Bay, Kanagawa. Attached 
Table 1. Results of screening tests for a slime film and an antifouling silicon type paint by present method

\begin{tabular}{|c|c|c|c|c|c|c|}
\hline \multirow{2}{*}{\multicolumn{2}{|c|}{ Test material }} & \multirow{2}{*}{$\begin{array}{l}\text { No. of } \\
\text { cyprids } \\
\text { examined }\end{array}$} & \multirow{2}{*}{$\begin{array}{c}\text { The survival } \\
\text { rate of } \\
\text { larvae }(\%)\end{array}$} & \multirow{2}{*}{$\begin{array}{l}\text { Total no. of } \\
\text { attached larvae } \\
(\%)\end{array}$} & \multicolumn{2}{|c|}{ No. of attached larvae on plate } \\
\hline & & & & & Control (\%) & Sample $(\%)$ \\
\hline \multirow{3}{*}{ Slime } & A & 1885 & 93 & $145 \quad(7)$ & (35) & $95 \quad(65)$ \\
\hline & B & 1349 & 89 & $113 \quad(5)$ & $(28)$ & $(72)$ \\
\hline & $\mathrm{C}$ & 2259 & 97 & 243 & (39) & $148 \quad(61)$ \\
\hline \multirow{2}{*}{$\begin{array}{c}\text { AF Silicon } \\
\text { paint }\end{array}$} & A & 568 & 69 & (2) & $16(100)$ & 0 \\
\hline & B & 813 & 90 & $23 \quad(4)$ & $23(100)$ & 0 \\
\hline
\end{tabular}

bacteria was counted at about $10^{4}$ cells $/ \mathrm{mm}^{2}$ on it. A silicon type paint, which is one of the antifoulants and known to be highly preventive of biofouling, was coated on glass plates. Untreated glass plates were used as control in the two experiments.

More than $80 \%$ of the larvae used in each screening test were cyprids at the end of the experiments. Results for the two experiments are shown in Table 1. Three trials were performed on the selectivity for substrata between the slime and control plate. The survival rate of larvae was $89 \sim 97 \%$. Percentage of attachment was $5 \sim 18 \%$; and $61 \sim 72 \%$ of the attached cyprids chose the slime plates. On the other hand, in the two trials using silicon paint plates, the survival rate was $69 \%$ or $90 \%$. Percentage of attachment was as low as $2 \%$ or $4 \%$. Nevertheless, all of the attached cyprids chose the control plates.

These results confirm that this method is practical for the assay of test substances in the laboratory. In addition, this method is also useful for the evaluation of toxicity of various substances by following the survival rate of larvae. Evaluation of various substances for their inducing or inhibiting properties on larval attachment are now in progress using this methods.

\section{References}

KADO, R. (1991). Effect of light on the larval development of Balanus amphitrite DARWIN (Cirripedia). Nippon Suisan Gakkaisi, 57, 1821-1825.

Maki, J. S., D. Rittschof, J. D. Costlow and R. MitChell (1988). Inhibition of attachment of larval barnacles, Balanus amphitrite, by bacterial surface films. Mar. Biol., 97, 199-206.

Rittschof, D., E. S. Branscomb and J. D. Costlow (1984). Settlement and behavior in relation to flow and surface in larval barnacles, Balanus amphitrite DARWIN. J. Exp. Mar. Biol. Ecol., 82, 131-146.

\section{摘 要}

フジツボの付着期幼生を用いた付着関連物質のスクリー ニング法とその検討

フジッボのキプリス幼生の付着率を判定基準として, 付着促進または防止物質のスクリーニング法を考案しそ の有効性を検討した。試験は $8 l$ の海水を入れた水槽に 目合い $96 \mu \mathrm{m}$ の篩綟籠を垂下し, 試験板と対照板とキ プリス幼生を収容後, 海水を循環させ $24^{\circ} \mathrm{C}$ 暗条件下で 72 時間放置後の試験板之対照板への幼生の付着率を求 める. 本法により海域に浸漬して形成させたスライムと シリコン系防污塗料について試験した結果, 前者には付 着促進, 後者には付着防止効果が認められた。

勝山一朗 (日本エヌ・ユー・エス (株) 環境事業部)，加戸 隆介 (北里大学水産学部), 小南寛彦 (関西電力 (株) 総合 技術研究所), 北村 等 (長崎大学水産学部) 